\title{
Some body measurements as a management tool for Shami goats raised in subtropical areas in Egypt
}

\author{
Abd-Allah, S*, H. H. Abd-El Rahman, M. M. Shoukry, M. I. Mohamed, Fatma M. Salman and A. A. Abedo
}

\begin{abstract}
Background: This filed work was conducted to describe the morphological features of Shami goats in subtropical areas in Egypt. The study covered Southern Sinai and Noubaria districts in Egypt. Data were collected from 30 goats of different age groups. Fifteen were males and 15 were females.

Results: Results show that male was heavier and longer than female. The mean live body weight (LBW) of the male group was $35.40 \mathrm{~kg}$, while that of female group was $33.46 \mathrm{~kg}$. However, these differences were not significant $(P>0.05)$. The body length (BL) of male recorded $77.80 \mathrm{~cm}$, while that of the female was $74.73 \mathrm{~cm}$. Similarly, the heart girth $(\mathrm{HG})$, as well as withers height $(\mathrm{WH})$, was also higher $(P<0.05)$ in male than those of the female. Both HG $(r=0.98)$ and neck circumference (NC) $(r=0.96)$ presented the highest correlations with LBW of males, while the measurements of BL and head length (HEL) presented the highest correlations $(r=0.95-0.86)$ with LBW of females. Live body weight of the male was accurately and significantly $(P<0.01)$ predicted by the measurements of $\mathrm{HG}$ and NC with $R^{2}=0.98$. While $B L$ and paunch girth $(P G)$ were significantly $(P<0.01)$ used to predict $L B W$ of the female with $R^{2}=0.92$. Stepwise regression analysis determined that $\mathrm{BL}$ and $\mathrm{HG}$ were the major significant contributors to the LBW prediction equation of total (male and female). Body length was the first independent variable to enter the model followed by $H G, N C$, and PG entered the best-fitted regression models. Thus, they were the variables entered to obtain the optimal regression models. The high correlation values between predicted and actual live body weight measurements give credence to the validity of using these models for predicting live weights of Shami goats.
\end{abstract}

Conclusions: From this data, it could be concluded that the live weight can be predicted with high accuracy from some body measurements which can be exploited by goat producers for management, selection, and genetic improvement of Shami goats and could be used successfully in new breeding programs in Egypt.

Keywords: Body measurements, Management, Regression, Shami goats, Egypt

\section{Introduction}

Phenotypic characterization of animal genetic resources (AnGR) is the process of identifying distinct breeds by describing their external and production characteristics in a given environment and under given management, taking into account the social and economic factors. The information generated by phenotypic characterization studies is essential for planning the management of AnGR at local, national, regional, and global levels (FAO, 2012). The global plan of action for AnGR recognizes that a good

\footnotetext{
* Correspondence: Sablogical2007@yahoo.com

Animal Production Department, Agriculture and Biology Division, National Research Centre, 33 El-Bohouth Street, Dokki, Giza 12622, Egypt
}

understanding of breed characteristics is necessary to guide decision-making in livestock development and breeding programs (FAO, 2007).

In the last few years, there has been a growing interest in breeding schemes. Quite recently, considerable attention has been paid to breeding programs of goats. Breeding programs of goats are widely carried out in many countries of the world and have led to the development of several specialized breeds (Abd-Allah, 2014; Abd-Allah et al., 2015 and 2016; Dubeuf et al., 2004; Morand-Fehr and Lebbie, 2004). Phenotypic characterization is essential in mapping out an inventory of characteristics peculiar to a group of animals and sustainable use of its animal genetic resources. Lack of information on characterization of the genetic 
resource may lead to underutilization of that resource, its replacement, and dilution through crossbreeding despite their local adaptation to prevailing environmental constraints (Manzi et al., 2011). Several breeding programs were applied on Shami goats in Syria, Cyprus, and Lebanon. However, in a review on goat breeding comparing the performance of many of the world breeds, there was a little reference to the Shami (Damascus) goat (Shrestha and Fahmy, 2007a and b). Shami goats obtained importance in recent years, as it is a specialized breed that could increase the productivity of Egyptian goat and reduce kid production costs. Although, weight is an important objective in a selection, the potential for genetic improvement largely depend on the genetic and phenotypic parameters of this trait upon which selection may be applied (Mavrogenis et al., 1984 and Das et al., 1996). Moreover, environmental influences can be controlled and corrected to permit more accurate identification of genetic differences between individual goats (Hermiz, 1998). During selection of goat, attention should be given to the age, growth rate, LBW, HG, $\mathrm{BL}$, and $\mathrm{WH}$. The prediction of $\mathrm{BW}$ and its relationships to other morphological measurements produces appreciable knowledge for breeding investigation with regard to meat production per animal (Janssens and Vandepitte, 2004; Yilmaz et al., 2013 and Iqbal et al., 2013). The net result of dependence on estimated live body weights is inefficiencies in both the management of animals and inconsistencies in prices of goats which all work against the farmer. Availability of a weight band and farmer training on how to use it would assist resource-poor farmers in implementing good animal husbandry practices. The present experimental work, therefore, was undertaken to characterize some body characteristics of Shami goat and has been used to determine the best-fitted regression model for prediction of live body weight in subtropical districts such as South Sinai and Noubaria in an effort to develop local goat breeding strategy in Egypt.

\section{Materials and methods}

\section{Description of the study area}

During the period between 2015 and 2016, sampling was carried out in two selected governorats in subtropical areas in Egypt, namely Southern Sinai and Noubaria region, respectively. A total of 30 Shami goats (15 females and 15 males) located in two selected states. Experimental area has an arid climate with hot dry summer and cool winter prevailing in this area.

\section{Experimental procedure Sampling procedure}

All procedures and experimental protocols were conducted in accordance with the Guide for the Care and
Use of Agricultural Animals in Research and Teaching, Federation of Animal Science Societies (FASS, 2010). Two groups which contain 30 of bucks and does of Shami goats. The first group (southern Sinai region) involved 16 heads (10 males and 6 females), aging 1.5-3.5 years, while the second group (Noubaria region) was formed by 14 heads ( 5 males and 9 females) aging 1.4 years.

According to the environmental conditions at the two sites under study, all goats were kept under equal management and the ration was offered daily in two parts at $9 \mathrm{am}$ and $4 \mathrm{pm}$, approximately. Fresh water and salt blocks were available continuously during the experimental period. All animals were fed on concentrate feed mixture (CFM), consisted of $17 \%$ wheat bran, $15 \%$ cotton seed meal, $50 \%$ yellow corn, $15 \%$ sunflower meal, $2 \%$ limestone, and $1 \%$ salt, according to their live body weight (NRC,1981), plus free available green Acacia and Atriplex or bean straw, where Acacia saligna and Atriplex halimus were collected daily from the experimental farm in El-Tor city, South Sinai.

\section{Data collection}

Assessment of live body weight (LBW) Goats were weighed individually by using a pallet balance of $500 \mathrm{~kg}$ capacity, where this body weight was recorded in the morning before the animals were fed.

Assessment of body linear measurements The linear dimensions measured included the following eight linear body measurements: heart girth (HG), wither height $(\mathrm{WH})$, body length (BL), chest depth $(\mathrm{CD})$, head length (HEL), paunch girth (PG), shank circumference (SC), and neck circumference $(\mathrm{NC})$.

The height measurement $(\mathrm{cm})$ was done using a graduated measuring stick. The measurements were taken in the morning, with the animals standing on a flat surface with head held up and held by three field assistants. The length and circumference measurements $(\mathrm{cm})$ were effected using a tape rule. All measurements were carried out by the same person in order to avoid individual variations.

The measurements were taken as follows:

1. Heart girth (HG) was measured as a circumferential measure taken around the chest just behind the front legs and withers.

2. Wither height $(\mathrm{WH})$ was measured as the distance from the surface of a platform to the withers.

3. Body length (BL) was the distance from the base of the ear to the base of the tail (where it joins the body).

4. Chest depth (CD) was measured as vertical distance from sternum to withers. 
5. Head length (HEL) was the distance measured from nodule of the horn to the upper lip of the animal.

6. Paunch girth (PG) was measured as the circumference of the body immediately after the abdomen just before the hind legs.

7. Shank circumference (SC) was measured from the left mid metacarpus.

8. Neck circumference (NC) was measured as the circumference of the neck at the midpoint.

\section{Data analysis}

The program SPSS (2008) statistical package designed for windows was used for the statistical analyses. Means were separated using the two-tailed, two-sample $t$ test. Differences were considered to be significant at $P<0.05$. Relationships between the several body measurements were calculated by Pearson correlations, and regression equations were established. Live body weight was regressed on linear body measurements using stepwise multiple linear regression analysis. The coefficient of determination $\left(R^{2}\right)$ was used to assess the accuracy of prediction equations between live body weights and linear body measurements. Separate prediction equations were developed for the male and female.

\section{Results}

Descriptive analysis of body weight and morphological traits Descriptive statistics of LBW and morphometric traits of Shami goats are shown in Table 1. The results showed that there was a numerical mean difference between males and females in all morphometric measurements. However, these differences were not significant $(P<0.05)$ indicating for $\mathrm{HG}, \mathrm{WH}, \mathrm{BL}, \mathrm{CD}, \mathrm{HEL}$, and PG. Average live body weight was not significantly $(P<$ $0.05)$ higher in males than in females. While male had higher $(P<0.05) \mathrm{SC}$ and NC.

\section{Bivariate correlations between body weight and} measurements of Shami goats

The correlation coefficient between live weight and body measurement of the two sexes are shown in Table 2. It is clear that the majority of correlation coefficients between measurements were high and significant $(P<0.01)$ in both males and females. The highest and strongly positive correlation $(P<0.01)$ was recorded between live body weight and heart girth (0.98) for the male and of body length (0.95) for female goats. On the other hand, lower estimates were recorded for the correlation of LBW with both CD $(r=0.76)$ for male and of $\mathrm{NC}(r=0.69)$ for female does.

\section{Prediction of body weight from body measurements}

Based on the importance of the independent variables in predicting the live weight of Shami goats, three body measurements, namely $\mathrm{BL}, \mathrm{HG}$, and $\mathrm{NC}$ were found to be more efficient. Body length was the first independent variable to enter the model followed by hip HG, and NC entered the best-fitted regression models. Thus, they were the variables entered to obtain the optimal regression models. It is necessary here to say that live weight of Shami goats can be predicted from BL and HG with a coefficient of determination 0.92 and HG and NC with a coefficient of 0.98 for Shami male. Heart girth was not the best variable to estimate live body weight for female goats. It was the BL and PG with a coefficient of 0.93 , which was used to estimate weight for female. The best-fitted regression models in each group were included in Table 3.

\section{Weight values corresponding to $\mathrm{HG}$ and BL measures for male and female of Shami goats}

Predicted live weights based on HG measurements had a 0.96 correlation coefficient to the actual live body weights for male, while predicted live weights obtained using BL model gave a correlation coefficient of 0.90 to the actual live body weights for female (Table 4).

Table 1 Descriptive statistics of the morphological traits of Shami goats based on sex

\begin{tabular}{|c|c|c|c|c|c|c|c|c|c|c|}
\hline \multirow[t]{2}{*}{ Traits } & \multicolumn{4}{|c|}{ Shami goats $(n=30)$} & \multicolumn{3}{|c|}{ Male $(n=15)$} & \multicolumn{3}{|c|}{ Female $(n=15)$} \\
\hline & Mean & SE & SD & CV (\%) & Mean & SE & SD & Mean & SE & SD \\
\hline LBW & 34.43 & 1.95 & 10.68 & 31.01 & $35.40^{\mathrm{a}}$ & 3.05 & 11.82 & $33.46^{a}$ & 2.51 & 9.73 \\
\hline$H G$ & 76.43 & 1.85 & 10.18 & 13.31 & $78.73^{\mathrm{a}}$ & 3.04 & 11.79 & $74.13^{\mathrm{a}}$ & 2.07 & 8.03 \\
\hline WH & 64.96 & 1.18 & 6.51 & 10.02 & $64.80^{\mathrm{a}}$ & 1.94 & 7.54 & $65.13^{\mathrm{a}}$ & 1.43 & 5.56 \\
\hline$B L$ & 76.26 & 1.84 & 10.09 & 13.23 & $77.80^{\mathrm{a}}$ & 2.54 & 9.86 & $74.73^{\mathrm{a}}$ & 2.69 & 10.43 \\
\hline$C D$ & 34.83 & 0.74 & 4.06 & 11.65 & $35.80^{a}$ & 1.06 & 4.12 & $33.86^{\mathrm{a}}$ & 1.00 & 3.88 \\
\hline SC & 8.40 & 0.21 & 1.19 & 14.16 & $8.86^{\mathrm{a}}$ & 0.36 & 1.40 & $7.93^{b}$ & .180 & .700 \\
\hline HEL & 17.93 & 0.31 & 1.74 & 9.70 & $18.06^{\mathrm{a}}$ & 0.45 & 1.75 & $17.80^{\mathrm{a}}$ & .450 & 1.78 \\
\hline PG & 33.20 & 0.69 & 3.82 & 11.50 & $32.93^{\mathrm{a}}$ & 2.13 & 8.28 & $33.46^{\mathrm{a}}$ & 2.11 & 8.20 \\
\hline NC & 33.06 & 1.20 & 6.62 & 20.0 & $36.26^{a}$ & 1.93 & 7.48 & $29.86^{b}$ & .920 & 3.58 \\
\hline
\end{tabular}

Superscripts $\mathrm{a}$ and $\mathrm{b}$ mean within rows are significantly different $(P<0.05)$

$S D$ standard deviation, $S E$ standard error, $C V$ coefficient of variation 
Table 2 Bivariate correlations among morphological traits and LBW of male (above diagonal) and female (below diagonal) Shami goats

\begin{tabular}{llllllllll}
\hline Traits & LBW & HG & WH & BL & CD & SC & HEL & PG \\
\hline LBW & - & $0.979^{b}$ & $0.940^{b}$ & $0.905^{b}$ & $0.764^{b}$ & $0.922^{b}$ & $0.854^{b}$ & $0.854^{b}$ & $0.961^{b}$ \\
HG & $0.830^{b}$ & - & $0.969^{b}$ & $0.871^{b}$ & $0.731^{b}$ & $0.923^{b}$ & $0.779^{b}$ & $0.879^{b}$ & $0.915^{b}$ \\
WH & $0.796^{\mathrm{b}}$ & $0.761^{\mathrm{b}}$ & - & $0.821^{\mathrm{b}}$ & $0.593^{\mathrm{a}}$ & $0.899^{\mathrm{b}}$ & $0.699^{\mathrm{b}}$ & $0.785^{\mathrm{b}}$ & $0.853^{\mathrm{b}}$ \\
$\mathrm{BL}$ & $0.947^{\mathrm{b}}$ & $0.774^{\mathrm{b}}$ & $0.805^{\mathrm{b}}$ & - & $0.792^{\mathrm{b}}$ & $0.831^{\mathrm{b}}$ & $0.915^{\mathrm{b}}$ & $0.860^{\mathrm{b}}$ & $0.887^{\mathrm{b}}$ \\
$\mathrm{CD}$ & $0.715^{\mathrm{b}}$ & $0.718^{\mathrm{b}}$ & $0.799^{\mathrm{b}}$ & $0.729^{\mathrm{b}}$ & - & $0.782^{\mathrm{b}}$ & $0.753^{\mathrm{b}}$ & $0.721^{\mathrm{b}}$ & $0.820^{\mathrm{b}}$ \\
SC & $0.776^{\mathrm{b}}$ & 0.482 & $0.714^{\mathrm{b}}$ & $0.766^{\mathrm{b}}$ & $0.727^{\mathrm{b}}$ & - & $0.786^{\mathrm{b}}$ & $0.727^{\mathrm{b}}$ & $0.871^{\mathrm{b}}$ \\
HEL & $0.858^{\mathrm{b}}$ & $0.806^{\mathrm{b}}$ & $0.637^{\mathrm{a}}$ & $0.839^{\mathrm{b}}$ & $0.563^{\mathrm{a}}$ & $0.559^{\mathrm{a}}$ & - & $0.742^{\mathrm{b}}$ & $0.892^{\mathrm{b}}$ \\
PG & $0.846^{\mathrm{b}}$ & $0.842^{\mathrm{b}}$ & $0.786^{\mathrm{b}}$ & $0.765^{\mathrm{b}}$ & $0.712^{\mathrm{b}}$ & 0.490 & $0.707^{\mathrm{b}}$ & - & $0.811^{\mathrm{b}}$ \\
NC & $0.692^{\mathrm{b}}$ & 0.487 & $0.674^{\mathrm{b}}$ & $0.700^{\mathrm{b}}$ & $0.696^{\mathrm{b}}$ & $0.733^{\mathrm{b}}$ & $0.578^{\mathrm{a}}$ & $0.569^{\mathrm{a}}$ & - \\
\hline
\end{tabular}

${ }^{a}$ Correlation is significant at the 0.05 level (two-tailed)

${ }^{\mathrm{b}}$ Correlation is significant at the 0.01 level (two-tailed)

\section{Discussion}

Descriptive analysis of body weight and morphological traits The higher values reported for the morphometric traits of males compared to females seem in accordance with earlier reports on goats (Vargas et al., 2007). The results thus obtained in this study are likely connected with our previous studies. The previous results have shown that the higher live body weight of male kids after weaning may be attributed to their birth weight; this is because they were born heavier than females in crossbred Boer goats (Abd-Allah, 2014 and Abd-Allah et al., 2016). Isaac (2005) reported that sexual dimorphism in body size is clearly widespread among many mammalian taxa, with male-biased dimorphism being the more common, but certainly not the exclusive pattern. It is important that the coefficient of variation in the morphometric traits ranged from 9.70-20.0\%; this indicates homogeneity between traits under study. The findings of the present study show that $\mathrm{BL}$ is $76.26 \mathrm{~cm}$, HG is $76.43 \mathrm{~cm}$, and $\mathrm{WH}$ is $64.96 \mathrm{~cm}$ in Shami goats. The observations of the current investigation are somewhat different from those of Alsheikh (2013) who reported that low mean lives in BL, HG, and WH were 57.21, 31.66, and 41.76, respectively, in Shami does of the same environmental condition in Sinai, Egypt. Also, our values were higher than that reported by Moaeen-ud-Din et al.(2006) who reported $64.97 \mathrm{~cm}$ body length, $70.23 \mathrm{~cm}$ height at withers, and $61.29 \mathrm{~cm}$ heart girth, for crossbred goats. The variation in various body measurements in different studies on the same breed may be due to the difference in the environment, size of data set, and other management practices.

Table 3 Regression equations developed to estimate weight from linear body measurements of Shami goats

\begin{tabular}{|c|c|c|c|c|c|c|c|c|}
\hline Groups & Model & $R$ & $R^{2}$ & Adj. $R^{2}$ & S.E & $R^{2}$ change & F change & Sig. $F$ change \\
\hline \multirow[t]{5}{*}{ Total } & 1 & $0.917^{a}$ & 0.841 & 0.835 & 4.34079 & 0.841 & 147.846 & 0.000 \\
\hline & 2 & $0.961^{b}$ & 0.923 & 0.918 & 3.06535 & 0.083 & 29.148 & 0.000 \\
\hline & \multicolumn{4}{|c|}{ Model summary } & \multicolumn{4}{|c|}{ Regression equations } \\
\hline & \multicolumn{4}{|c|}{ a. Predictors: (constant), BL } & \multicolumn{4}{|c|}{$L B W=-200939.582+0.970^{*} B L$} \\
\hline & \multicolumn{4}{|c|}{ b. Predictors: (constant), BL, HG } & \multicolumn{4}{|c|}{$\mathrm{LBW}=-46.726+0.542^{*} \mathrm{BL}+0.521^{*} \mathrm{HG}$} \\
\hline \multirow[t]{5}{*}{ Male } & 1 & $0.979^{a}$ & 0.958 & 0.955 & 2.52153 & 0.958 & 294.891 & 0.000 \\
\hline & 2 & $0.992^{b}$ & 0.984 & 0.982 & 1.60140 & 0.027 & 20.231 & 0.001 \\
\hline & \multicolumn{4}{|c|}{ Model summary } & \multicolumn{4}{|c|}{ Regression equations } \\
\hline & \multicolumn{4}{|c|}{ a. Predictors: (constant), HG } & \multicolumn{4}{|c|}{$\mathrm{LBW}=-41.864+.981^{*} \mathrm{HG}$} \\
\hline & \multicolumn{4}{|c|}{ b. Predictors: (constant), HG, NC } & \multicolumn{4}{|c|}{$\mathrm{LBW}=-35.829+0.611^{*} \mathrm{HG}+0.637^{*} \mathrm{NC}$} \\
\hline \multirow[t]{5}{*}{ Female } & 1 & $0.947^{\mathrm{a}}$ & 0.897 & 0.889 & 3.23887 & 0.897 & 113.568 & 0.000 \\
\hline & 2 & $0.966^{b}$ & 0.933 & 0.922 & 2.72650 & 0.036 & 6.345 & 0.027 \\
\hline & \multicolumn{4}{|c|}{ Model summary } & \multicolumn{4}{|c|}{ Prediction equations } \\
\hline & \multicolumn{4}{|c|}{ a. Predictors: (constant), BL } & \multicolumn{4}{|c|}{$\mathrm{LBW}=-32.589+0.884^{*} \mathrm{BL}$} \\
\hline & \multicolumn{4}{|c|}{ b. Predictors: (constant), BL, PG } & \multicolumn{4}{|c|}{$\mathrm{LBW}=-48.080+0.675^{*} \mathrm{BL}+0.347^{*} \mathrm{PG}$} \\
\hline
\end{tabular}


Table 4 Predicted live body weight $(\mathrm{kg})$ of Shami goats given $\mathrm{HG}(\mathrm{cm})$ for male and $\mathrm{BL}(\mathrm{cm})$ for female

\begin{tabular}{llllllll}
\hline$N$ & Male & \multicolumn{5}{c}{ Female } \\
\cline { 2 - 5 } \cline { 7 - 8 } & HG $(\mathrm{cm})$ & ALBW $(\mathrm{kg})$ & PLBW $(\mathrm{kg})$ & & BL $(\mathrm{cm})$ & ALBW $(\mathrm{kg})$ & PLBW $(\mathrm{kg})$ \\
\hline 1 & 83.00 & 44.00 & 39.38 & 87.00 & 42.00 & 44.32 \\
2 & 96.00 & 53.00 & 52.31 & & 93.00 & 50.00 & 49.62 \\
3 & 97.00 & 53.00 & 53.29 & & 83.00 & 41.00 & 40.78 \\
4 & 72.00 & 30.00 & 28.77 & & 85.00 & 44.00 & 42.55 \\
5 & 75.00 & 33.00 & 31.70 & & 70.00 & 30.00 & 29.29 \\
6 & 80.00 & 33.00 & 36.54 & & 60.00 & 22.00 & 20.45 \\
7 & 82.00 & 36.00 & 38.58 & & 60.00 & 23.00 & 20.45 \\
8 & 58.00 & 14.00 & 15.00 & & 74.00 & 33.00 & 32.83 \\
9 & 69.00 & 23.00 & 25.83 & & 81.00 & 41.00 & 39.00 \\
10 & 61.00 & 20.00 & 17.97 & & 67.00 & 25.00 & 26.63 \\
11 & 83.00 & 43.00 & 39.56 & & 77.00 & 27.00 & 35.48 \\
12 & 96.00 & 52.00 & 52.31 & & 79.00 & 41.00 & 36.75 \\
13 & 72.00 & 30.00 & 28.77 & & 78.00 & 40.00 & 36.36 \\
14 & 75.00 & 32.00 & 31.71 & 60.00 & 20.00 & 20.45 \\
15 & 82.00 & 35.00 & 38.58 & 67.00 & 23.00 & 26.63 \\
\hline
\end{tabular}

ALBW actual live bodyweight, $P L B W$ predicted live body weight, $H G$ heart girth, $B L$ body length

\section{Bivariate correlations between body weight and measurements of Shami goats}

The results are supported by Abdel-Mageed and Ghanem (2013), who decided that both HG $(r=0.91)$ and BL $(r=0.90)$ presented the highest correlations with LBW of Shami kids. BL and HG may be used as good reliable predictors to assess live weight according to Bhattacharya et al. (1984) and Islam et al. (1991) reported that heart girth in males is a good predictor of live weight in Bengal goats. There was a correlation of LBW with length, height, and HG in Black Bengal goats (Prasad et al., 1981). Since there are high correlation coefficients between live body weight and body measurements, either of these variables or combination could provide a good estimate for predicting live weight in Shami goats. Khan et al. (2006) concluded that since the body measurements had a high correlation with the live body weight, this may be used as selection criteria. On the other hand, Ott (1986) recorded that determination of scrotal length and circumference is an important aspect of breeding soundness examination (BSE) and scrotal circumference has great value as an indicator of genetic trait, puberty, and total spermatozoa production.

\section{Prediction of body weight from body measurements}

According to the results of this study, the highest correlation was determined between LBW and HG in male group. These findings are in harmony with that of Bhattacharya et al. (1984) and Islam et al. (1991), who reported that body length and heart girth may be used as good reliable predictors to assess live weight according to reported that heart girth in males is a good predictor of live weight in Bengal goats. The result is generally in agreement with Taye et al. (2010) who reported that HG is the best predictor of weight. Nevertheless, HG parameter is the easiest way to use for live weight prediction in field conditions.

\section{Live weight values corresponding to HG and BL measures for male and female Shami goats}

The $R^{2}$ value of 0.96 for the exponential model with HG as the sole finding of this investigation in the study is in close agreement with de Villiers et al. (2009), who used nonlinear regression models on data collected from 1202 Boer goats and reported an $R^{2}$ value of 89.4 for a heart girth-based prediction model. The high correlation values between predicted and actual live body weight measurements give credence to the validity of using these models for predicting live weights of Shami goats. Also, the obtained results of this study is in close agreement with de Villiers et al. (2009), who indicted that measurements give credence to the validity of using these models for predicting live weights of Swazi goats.

\section{Conclusion}

Shami goats is one of the goats' breeds that can be used to improve the local breeds of goats genetically by crossing in Egypt, especially as it is an attractive morphological strain of great potential for milk and fattening compared with other local breeds in Egypt. In the same way, we may conclude that in order to practice good animal husbandry, the measurement of live body weight is totally essential for breeding, nutrition, and health management. The positive and significant correlation of weight with linear body measurements indicate that linear body measurements can be used as a marker to estimate weight using regression equations. In the current study, both of the effects of age and location study did not evaluate, but this area of research in subtropical Shami goat needs further studies with increasing the sample size to clarify the influence of each age and location on the predicting models.

\footnotetext{
Abbreviations

AnGR: Animal genetic resources; BL: Body length; CD: Chest depth; CFM: Concentrate feed mixture; FAO: Food and Agricultural Organization of the United Nations; FASS: Federation of Animal Science Societies; HEL: Head length; HG: Heart girth; LBW: Live body weight; NC: Neck circumference; PG: Paunch girth; SC: Shank circumference; SPSS: Statistical Package for Social Sciences; WH: Wither height
}

\section{Acknowledgements}

The authors gratefully acknowledge the technical and financial support of Agricultural Directorate in El-Tor city, South Sinai Governorate, through the project (Technology Transfer for the Development of Small Ruminant in Southern Sinai) in cooperation with Animal Production Department. National Research Centre. 


\section{Funding}

This research was funded by "The project (Technology Transfer for the Development of Small Ruminant in Southern Sinai) in cooperation with Animal Production Department, National Research Centre.

\section{Availability of data and materials}

The privilege of using and accessing morphological data used in this study is available to Animal Production Department. National Research Centre.

\section{Authors' contributions}

All authors wrote, read and approved the final manuscript.

\section{Ethics approval and consent to participate}

All procedures and experimental protocols were conducted in accordance with the Guide for the Care and Use of Agricultural Animals in Research and Teaching, Federation of Animal Science. Societies (FASS, 2010).

\section{Consent for publication}

Not Applicable.

\section{Competing interests}

The authors declare that they have no competing interests.

\section{Publisher's Note}

Springer Nature remains neutral with regard to jurisdictional claims in published maps and institutional affiliations.

\section{Received: 6 June 2018 Accepted: 3 January 2019}

\section{Published online: 31 January 2019}

\section{References}

Abd-Allah, S. (2014). Application of some crossbreeding and feeding programs to improve the productive performance in Baladi goats. Ph.D. Thesis, Fac. of Agric., Al-Azhar Univ. Nasr City, Cairo, Egypt.

Abd-Allah S, Mohamed Ml, Abd-Elrahman HH, EL-Kady RI (2016) Assessment of some productive performance of Boer goats and their crosses with Egyptian Baladi goats. Int J ChemTech Res 9(12):259-265 ISSN: 0974-4290

Abd-Allah S, Salama R, Mohamed MI, Mabrouk M, El-kady Rl, Kadry Al, Ahmed SM (2015) A comparative study on reproductive and productive performance of Boer and Baladi goats raised under similar environmental conditions in Egypt. Int J ChemTech Res 8(9):225-236 ISSN: 0974-4290

Abdel-Mageed I, Ghanem N (2013) Predicting body weight and longissimus muscle area using body measurements in subtropical goat kids. Egyptian Journal of Sheep and Goat. Sciences 8(1):95-100

Alsheikh SM (2013) Prediction of daily milk yield using different body measurements of Shami goats in Sinai. Egypt Am-Eurasian J. Agric Environ Sci 13(2):218-221

Bhattacharya B, Ghosh TK, Duttagupta R, Maitra DN (1984) Estimation of body weight in Black Bengal goats from body measurements. Indian Vet J 61:406-408

Das, S.M., Rege, J.E.O. and Shibre, M. (1996). Phenotypic and genetic parameters of growth traits of blended goats at Malya, Tanzania. Proceeding of The Third Biennial Conference of the African Small Ruminant Research Network. ILRI. p: 63-70.Nairobi, Kenya

De Villiers, J.F., Gcumisa, S.T. and Gumede, S.A. (2009). Estimation of live body weight from the heart girth measurement in KwaZulu-Natal goats. Applied Animal Husbandry \& Rural Development 2009, Volume 2 Retrived June 5, 2013

Dubeuf JP, Morand-Fehr P, Rubino R (2004) Situation, changes and future of goat industry around the world. Small Rum. Res 51:165-173

FAO (2007). Food and Agricultural Organization of the United Nations. Global plan of action for animal genetic resources and the interlake declaration. Rome (Accessed 07/ 01/ 2014)

FAO (2012). Food and Agricultural Organization of the United Nations. Phenotypic characterization of animal genetic resources. FAO Anima Production and Health Guidelines No.11. Rome, Italy

FASS (ed) (2010) Federation of Animal Science Societies. Guide for the care and use of agricultural animals in research and teaching, 3rd edn. FASS, Champaign

Hermiz HN (1998) Additive and multiplicative adjustment factors for milk traits in Iraqi local goat. Iraqi JAgric 3(2):164-173

lqbal M, Javed K, Ahmad N (2013) Prediction of body weight through body measurements in Beetal goats. Pakistan J Sci 65(4):458-461
Isaac $J$ (2005) Potential causes and life-history consequences of sexual size dimorphism in mammals. Mammal Rev 35:101-115

Islam MR, Saadullah M, Howlider MAR, Huq MA (1991) Estimation of live weight and dressed carcass weight from the different body measurements of goats. Indian J Anim Sci 61:460-461

Janssens S, Vandepitte W (2004) Genetic parametres for body measurement and linear type trait in Belgian Bleu du Maine, Suffolk and Texel sheep. Small Rumin Res 54:13-24

Khan H, Muhammad F, Ahmad R, Nawaz G, Rahimullah, Zubair M (2006) Relationship of body weight with linear body measurements in goats. J Agr Biol Sci 1:51-54

Manzi M, Rutagwenda T, Kanuya N, Hatikobo PC (2011) Phenotypic characterization of goats raised under traditional husbandry systems in Bugesera and Nyagatare districts of Rwanda. J Anim Veternary Adv 10(24): 3297-3302

Mavrogenis AP, Constantinou A, Louca A (1984) Environmental and genetic causes of variation in production traits of Damascus goats.1. Pre-weaning and post-weaning growth. Anim Prod 38:91-97

Moaeen-ud-Din M, Ahmad N, lqbal A, Abdullah M (2006) Evaluation of different formulas for weight estimation in Beetal, Teddi and crossbred (Beetal x Teddi) goats. J Anim Plant Sci 16(3-4):70-74

Morand-fehr P, Lebbie S (2004) Proposals for improving the research efficiency in goats. Small Rumin Res 51:145-153

NRC (1981) National Research Council. Nutrient Requirements of Goats: Angora, dairy and meats goats in temperate and tropical countries. National Academy Press, Washington D.C., p 250

Ott RS (1986) Breeding soundness examination of bulls. In: Morrow DA (ed) Current Therapy in Theriogenology. W. B. Saunder Co., Philadelphia, pp 125-136

Prasad B, Singh CSP, Mishra HR (1981) Note of body weight-measurement relationship in Black Bengal goats. Ind J Anim Sci 55:880-882

Shrestha JNB, Fahmy MH (2007a) Breeding goats for meat production: a review. (2) Crossbreeding and formation of composite population. Small Rumin Res 67:93-112

Shrestha JNB, Fahmy MH (2007b) Breeding goats for meat production: a review (3). Selection and breeding strategies. Small Rumin Res 67:113-125

SPSS (2008) Statistical package for social sciences for window, version 17.0. SPSS Inc., Chicago

Taye M, Bimerow T, Yitayew A, Mekuriaw SH, Mekuriaw G (2010) Estimation of live body weight from linear body measurements for Farta sheep. Online J Anim Feed Res 2(1):98-103

Vargas S, Larbi A, Sanchez M (2007) Analysis of size and conformation of native Creole goat breeds and crossbreds used in smallholder agro silvo pastoral systems in Puebla, Mexico. Trop Anim Health Prod 39:279-286

Yilmaz O, Cemal I, Karaca O (2013) Estimation of mature live weight using some body measurements in Karya sheep. Trop Anim Health Prod 45:397-403

\section{Submit your manuscript to a SpringerOpen ${ }^{\circ}$ journal and benefit from:}

- Convenient online submission

- Rigorous peer review

- Open access: articles freely available online

High visibility within the field

- Retaining the copyright to your article

Submit your next manuscript at $>$ springeropen.com 